УДК: 7.046

ББК: 85.155

A43

DOI: $10.18688 / \mathrm{aa} 188-1-15$

Giacomo Montanari

\title{
Between Poetry and Painting: Giovanni Andrea dell'Anguillara's Metamorfosi as a Model for Genoese Baroque Poets and Painters
}

The aim of this paper is to demonstrate how in Genoa, one of the greatest cities in which the new baroque culture rose, from the beginning and until the end of the $17^{\text {th }}$ century, the Metamorfosi's book written by Anguillara was used both as a model by literates for their baroque rhetorical composition and by painters as a more comprehensible and "modern" source of the "Antico" for their works of art.

As one of the most important sources of the Pagan mythological tradition and at the centre of the interest of great erudites as Francesco Petrarca and Giovanni Boccaccio during the $14^{\text {th }}$ century, the Metamorphosis written by Ovid were one of the most read books in the Western Europe during the $15^{\text {th }}, 16^{\text {th }}$ and $17^{\text {th }}$ centuries. Nevertheless, the text by Ovid, read today by scholars, is probably not the text widespread in all courts, palaces, villas, and painters' workshops between the $16^{\text {th }}$ and $17^{\text {th }}$ century. In fact, as well demonstrated by Guthmuller in several papers, the original Latin text was quite often replaced since the $14^{\text {th }}$ century by different versions translating the text into the vernacular language. Especially during the $16^{\text {th }}$ century, on the long wave of the success achieved by Ludovico Ariosto's and Torquato Tasso's epic poems, the text by Ovid was re-written by some Italian authors, such as Giovanni di Bonsignori, Giovanni Antonio Rusconi or Lodovico Dolce [5, pp. 23-56]. All of these versions, especially Rusconi's one, were reprinted in a lot of editions and sold in a large number of copies all around Europe, but the most important re-writing of the Metamorphosis by Ovid, still used during all the $18^{\text {th }}$ century and the principal source for mythological themes, is the one published in Venice in 1561 by Giovanni Andrea dell'Anguillara [5, pp. 129-147]. Anguillara's model is clearly Ariosto's poetry, not only concerning stylistic choices but, as we will see, even in respect to the narrative plot of the mythological events [5, pp. 88-98; 14, pp. 276-293].

Considering that the Anguillara's Metamorphosis fame was quite a global phenomenon, it could be very interesting to search for the consequences of this important model in a delimited area, applying some limits in time and space to the research. Coming from seventy years of wellness and growth in richness, power, arts, and culture, the Republic of Genoa represents the ideal place in which new ideas of renovation can grow freely (even due to the particular form of government) into the hand of a communitas studiorum composed by aristocrats, literates, and painters. 
Indeed, at the beginning of the $17^{\text {th }}$ century, Genoa was one of the most important European cities in which the new Baroque culture developed. This new culture necessarily had to use a new language, based on two main lines of research: the strong inspiration to the antiquity models (the Antico) and the adherence to nature itself (the imitatio naturae). In this climate of renovation, both literates and painters did their part to pursue those researches and wrote or painted their works of arts to show their new achievements. Anguillara's poem seems to be indeed one of the most important sources (together with Ariosto's Orlando Furioso and Tasso's Gerusalemme Liberata) for the literary production of Giovanni Vincenzo Imperiale, a rich member of Genoese aristocracy and a great literate [3, pp.17-30], and, in particular, for the Stato Rustico, published for the first time in 1607 and then reprinted in Venice in 1613.

Imperiale was one of the greatest collectors of paintings, sculptures and books during the whole $17^{\text {th }}$ century in the Republic of Genoa. His library, recently studied and published entirely for the first time [26, pp.269-282], shows active interest for Greek and Latin authors (such as Plutarch, Ovid, Giuseppe Flavio and others), for Ariosto and especially for Tasso's works, to which the young Giovanni Vincenzo was called to write the introduction to the 1604 edition. The presence of Anguillara's Ovid in his library, as in the Giulio Pallavicino's one (in two different copies) and in many others Genoese palaces, attests the great importance of this literary work in the cultural landscape of the Superba at the beginning and during the whole $17^{\text {th }}$ century [25, pp. 41-52].

The particular poetical choices, the stylistic background and the themes presented by Imperiale in his Stato Rustico clearly show his debt to Tasso, Ariosto, and Anguillara; and at the same time is very evident his will of making a change in the traditional Italian "epic" poetry, inherited from the great models of the Greek and Latin authors such as Homer, Ovid, and Virgil. Inspired by these examples, Imperiale had to deal with new ideas growing into the Genoese cultural landscape: he thought that arts (for examples literary production or paintings, which he frequently compared in his poetical works) had to represent nature in a more clear way, describing with their media (pen or brush, verses or colours, for example) what they can see in the world. Those new ideas, in particular this parallelism taken from the Oratian motto $u t$ pictura poesis, were brought by Giovan Battista Marino into his first work, such as the Dicerie Sacre (printed in Turin in 1614) and developed on a larger scale in his most famous works: the Galeria (1619) and the Adone (1623). The contacts between Marino and Genoa, in particular with Giovanni Carlo Doria and Giovanni Vincenzo Imperiale are well-known thank to some survived letters, but now it seems very clear that this link was not merely "diplomatic" relations with potential protectors: Marino was influenced deeply by Imperiale's first works, which he considered as models for his future production [12, pp.95-118]. In this way it is very easy to comprehend the legacy of Anguillara in Marino and in all the baroque culture of the $17^{\text {th }}$ century: the models of Imperiale came directly from the great Italian tradition such as the Furioso and the Gerusalemme, successfully mixed into the Ovidian myths re-written by Anguillara and all those themes and stylistic models arrived directly to Marino during his first formation as a literate [18, pp.15-44]. At the same time, the double-face of personalities such as Imperiale as collectors and literate represents the other turning point: Imperiale personally deals with painters, he knows their techniques, and shares his personal researches on the new ideas of imitatio naturae and love for antiquity. Painters and poets, in the very first decades of the $17^{\text {th }}$ century, in 
Genoa, are simultaneously developing new lines of the baroque sensibility. Domenico Fiasella, Orazio De Ferrari, Luciano Borzone, Grechetto, and others were the young pioneers of the baroque painting, coming from the legacy of Luca Cambiaso and especially Giovanni Battista Paggi, who died in 1627 [32, pp. 231-305; 19, pp.215-234].

During the decade starting from 1633 until 1643, the leadership of the Genoese "Literary Academy" completely changed. Giovanni Vincenzo Imperiale was sent in exile, and emerged the personality of Anton Giulio Brignole Sale, a great literate and the heir of a very powerful family. In discontinuity with Imperiale, who thought and spoke about an equity between painters and poets, Brignole Sale started to claim the superiority of poetry introducing into his texts the rhetorical figure of ekphrasis based on canvases painted by contemporary painters. In fact, describing those marvellous works of art with his baroque prose, Brignole Sale wanted to specify that words can go beyond the evocative power of images, describing even what the eyes can't see or imagine and catch the viewer emotions in a complete way. The model for this trouvaille were the classical examples of authors such as Lucian and Pliny the Elder, but the aim was completely different: Anton Giulio wanted to became an unquestioned leader of the Genoa's politic landscape, to force the Republic into a new politic line that aims to separate the destiny of Genoa from that of the Spanish Kingdom [22, pp.351-389; 7, pp. 277-282; 35, pp. 297-302].

For this reason, Anton Giulio and his first pupil, Luca Assarino, tried to demonstrate with facts that poetry (so the literates) was the most important of the liberal arts instead of painting and other artistic expressions, very popular in the Genoa's area. But the more interesting point is to verify that, in this climate of competition, the two rivals (poets and painters) took inspirations from the same source: Anguillara's Metamorphosis. Concerning this point, It is very important to consider this canvas by the Genoese painter Orazio De Ferrari representing the myth of Latona Turning the Men of Lycia into Frogs (Fig. 1) because we can read its description in a text by Assarino, who claimed he was carefully describing the canvas. Comparing the painting with the Ovidian myth, we can observe that Orazio De Ferrari used in a very explicit way the text by Anguillara and not the classical Latin version: Ovid said that Latona raised both hands to the sky to ask for the Gods' help, but (as we can see on the canvas) Anguillara wrote that she raised only one hand, because she was keeping her two young children, Apollo and Diana in her other hand. At the same time, the text by Assarino was inspired clearly by the poetical text by Anguillara, not by the Latin source and only partially by Orazio's canvas. Anguillara, in fact, described with a lot of details the transformations of the men into frogs, a detail repeated in the same sequence by Assarino, but not completely depicted by Orazio De Ferrari. In Orazio's canvas in fact only one man is turned into a frog, but on the contrary, both Anguillara and Assarino spoke about a "group transformation": all the men who insulted Latona became frogs at the same time. The role of Anguillara's text as an intermediary source that was used both by poets and painters is very visible in another interesting case study: the description of the canvas owned by Agapito Centurione and painted by Domenico Fiasella, representing Venus and Mars Caught in Adultery by Volcano. We have today two different ekphrasis of this canvas, the first one written by Anton Giulio Brignole Sale in the book Le Instabilità dell'Ingegno, printed in 1635; and the second written by Luca Assarino in a letter published in 1637. Unfortunately, today we don't know anything about the painting and it is impossible to read clearly the adher- 


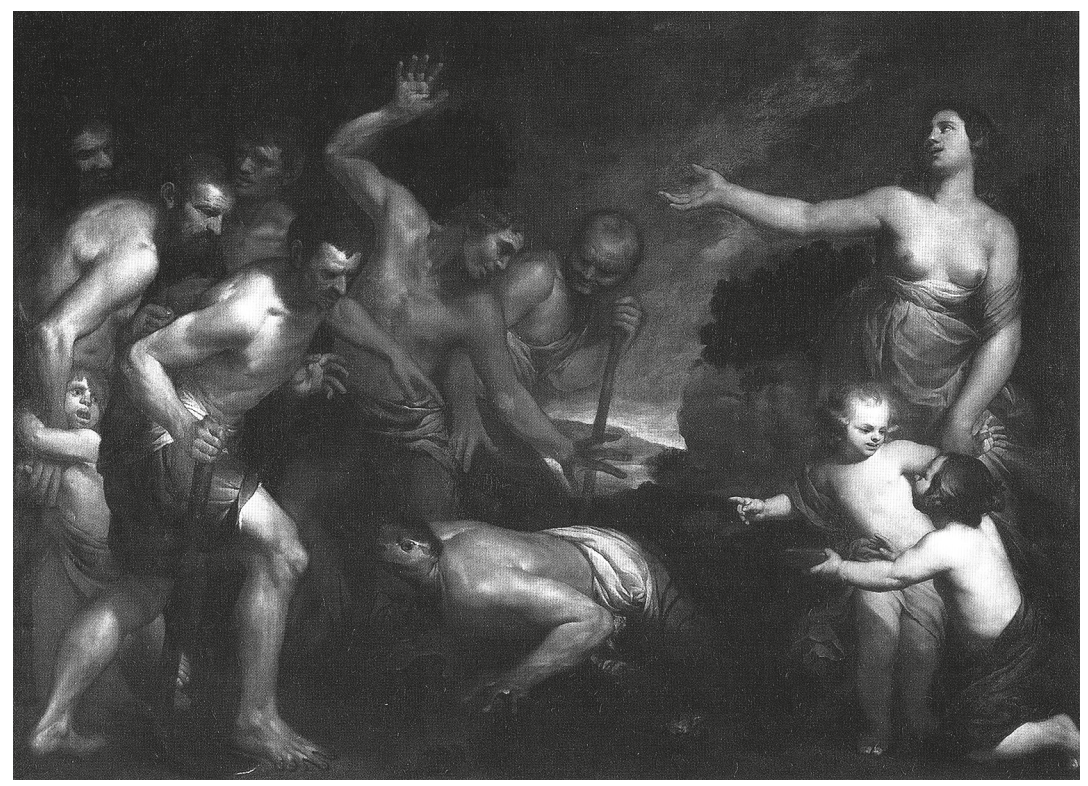

Fig. 1. Orazio De Ferrari. Latona changing the men of Lycia into frogs. c. 1640. Private collection

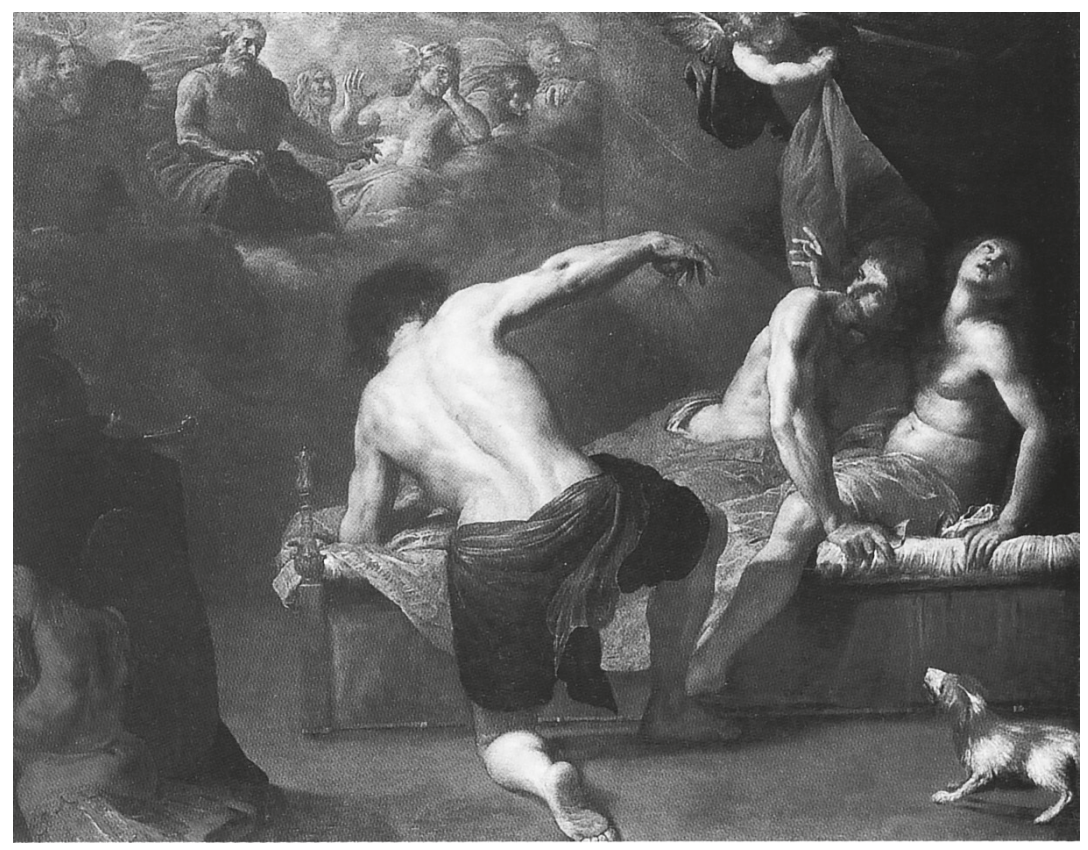

Fig. 2. Giovanni Battista Carlone. Venus and Mars caught in adultery by Volcano. c. 1650. Pinacoteca Civica, Savona 
ence of Fiasella's work to the words written by Brignole Sale and Assarino. We can imagine it looked like something similar to the canvas by Giovanni Battista Carlone (painted around the same period, Fig. 2), but the descriptions lead us to argue that the work by Fiasella had a quite different composition. What we can consider, on the other hand, are the literary models used by the two Genoese literates: they merged the themes coming from Anguillara's Ovid and those linked to the poetical tradition of this love-theme (Homer and Lucian), but very few links can be seen with Marino's Adonis, where the poet describes in a long series of verses the mythological novel of the love between Venus and Mars.

I think that the idea of a new baroque language that tries to go beyond the glorious tradition starting from its achievements can explain this phenomenon quite well: Marino's baroque poetry necessarily was born into the sensibility of literates who are still watching at the "classical" tradition and it is important to note that the influence went from them to him and not vice versa, from him to them. In this case, we can state that Genoa was one of the most up to date European literary circles at the beginning of the $17^{\text {th }}$ century, a model used by the most important personality of that century as a real paradigma [20, pp. 29-39].

If this statement is certainly true for the first four decades of the $17^{\text {th }}$ century, the situation completely changed at the end of the Seicento. The decadence of the Spanish Kingdom, which enhanced the economic power of the Genoese aristocracy, and the new European leadership of the French King Luis XIV, changed the centrality of Genoa into something quite similar to a suburbs of the major cities at the end of the century: Paris, Rome, and Turin. Nevertheless, even if had ended the communitas studiorum in which the idea of the baroque "revolution" in word and image took place, Anguillara's book was still one of the most important sources for the Genoese painters. One of the greatest examples is linked to a cycle of three great canvases now owned by the Galleria Nazionale of Palazzo Spinola in Genoa and originally placed in Palazzo Spinola Adorno in Strada Nuova. The themes are obviously three myths taken from the Metamorphosis, but the painters Gregorio and Lorenzo De Ferrari (father and son) kept their brushes incredibly close to the text by Anguillara. The great canvas representing the Birth of the Coral or Perseus and Andromeda for example (Ill.21), represents Pegasus, absent in Ovid, but inserted as a similitude with the hippogryph ridden by Astolfo in the Furioso [14, pp. 283-285]. The winged horse is tied to a palm tree, as described by Anguillara, and Perseus is washing his hands with the sea water, perfectly adherent to the text, word by word. This adherence is very strict even on the canvas describing Pan and Syrinx, a great masterpiece by the hand of Gregorio De Ferrari (Ill. 22), realised in the last decade of the $17^{\text {th }}$ century. Anguillara describes Syrinx's escape from Pan using a metaphor: Pan is described as "hot" because he was inflamed by love passion, Syrinx fleeing is shown as "cold" because she fears to be raped by the faun. Gregorio De Ferrari perfectly follows these poetical indications: Pan is painted with ocher colours, representing him as a true earth-god full of feral instinct; Syrinx, on the contrary, is painted in white ivory colour with light blue shades, to represent her lack of love passion, her coldness, as Anguillara wrote. The third canvas, made probably together by Gregorio and Lorenzo, describes Mercury killing Argus (Ill.23) [39, p. 85]. Mercury is depicted in the precise moment in which he is leaving his syrinx and pulls out the sword to behead Argus while he is asleep. Anguillara narrates in fact that Mercury played and sang to Argus the myth of Pan pursuing Syrinx to make him fall asleep, creating a real link between the two mythological stories, a sort 
of "myth into the myth", used by Gregorio De Ferrari and his patron (who is still unknown) even to choose the different episodes to create a narrative link between the canvases.

Those examples of the use of Anguillara's book as a source at the end of the $17^{\text {th }}$ century, testify the great importance of this text in the cultural landscape of Genoese baroque painters, but also, at the same time, shows how they maintain the same models for almost a century. Anguillara's Metamorphosis were, at the beginning of the century, a milestone for people as Giovanni Vincenzo Imperiale, Anton Giulio Brignole Sale, and Luca Assarino as literates and Orazio De Ferrari, Domenico Fiasella, and Giovanni Battista Carlone as painters, who started to renovate the mannerist tradition into the new baroque language, based on the inspiration from the nature itself and on the idea of the importance of the antiquity's legacy. A common source, used by two different categories of 'artists', represents in what way in some periods the Arts went on onto the same path, watching one to the other into a mutual relationship extremely useful to the development of a new, revolutionary language as was the baroque art and literature.

\section{References}

1. Aiolfi R.; Barbero B.; Varaldo C. (eds.). La Pinacoteca civica di Savona. Savona Publ., 1975. 235 p. (in Italian).

2. Assarino L. Raguagli di Cipro. Dedicati al molto illustrissimo Sig. Capitano Gioseffo Ciccolini, Nobile Todino. Bologna; Macerata, per il Grisei Publ., 1642. 233 p. (in Italian).

3. Beltrami L. Tra Tasso e Marino: Giovan Vincenzo Imperiali. Alessandria, Edizioni dell'Orso Publ., 2015. 221 p. (in Italian).

4. Besomi O. Fra i ritratti del Giovio e del Marino. Schede per la Galeria. Lettere Italiane, 1988, vol. 40, no. 4, pp. 511-521 (in Italian).

5. Bucchi G. “Meraviglioso diletto". La traduzione poetica e le Metamorfosi d'Ovidio di Giovanni Andrea dell'Anguillara. Pisa, Edizioni ETS Publ., 2011. 396 p. (in Italian).

6. Croce F. Genova e il Barocco letterario. Genova nell'Età Barocca, catalogo della mostra (Genova, 2 maggio -26 luglio 1992). E. Gavazza; G. Rotondi Terminiello (eds.). Bologna, Nuova Alfa Editoriale Publ., 1992, pp. 509-515 (in Italian).

7. De Caro G. Anton Giulio Brignole Sale. Dizionario Biografico degli Italiani, 1972, vol. 14, pp. 277-282 (in Italian).

8. De Laurentiis E. Latona converte en ranas a los campesinos de Licia. Maestros del Barroco Europeo. Madrid, Galleria Jorge Coll e Nicolàs Cortés Publ., 2005, no. 25, pp. 84-86 (in Spanish).

9. Dell'Anguillara G. A. Le Metamorfosi di Ovidio ridotte da Giovanni Andrea dell'Anguillara in ottava rima, con le Annotazioni di M. G. Horologgi, 3 vols. Venezia, Giunti Publ., 1584. 486 p. (in Italian).

10. Donati P. Domenico Fiasella. Genova, Sagep Publ., 1990. 288 p. (in Italian).

11. Donati P. Orazio de Ferrari. Genova, Sagep Publ., 1997. 192 p. (in Italian).

12. Farina V. Giovan Carlo Doria promotore delle arti a Genova nel primo Seicento. Firenze, Edifir Publ., 2002. 288 p. (in Italian).

13. Guardiani F. L'idea dell'immagine nella galleria di G. B. Marino. Letteratura italiana e arti figurative, Atti del XII convegno dell'Associazione internazionale di studi di lingua e letteratura italiana (Toronto-HamiltonMontreal, 6-10 maggio 1985). A. Franceschetti (ed.). Firenze, Accademia Editoriale Publ., 1988, pp.647654 (in Italian).

14. Guthmuller B. Mito e Metamorfosi nella letteratura italiana. Da Dante al Rinascimento. Roma, Carocci Publ., 2009. 306 p. (in Italian).

15. Imperiale G. V. Lo Stato Rustico, vol. 2. Genova, presso il Pavoni Publ., 1607. 703 p. (in Italian).

16. Lee R. W. Ut pictura poesis, la teoria umanistica della pittura. Firenze, Sansoni Publ., 1974. 135 p. (in Italian).

17. Lòpez-Bernasocchi A. Tradizione e innovazione in un poema del Seicento: lo Stato rustico di Gian Vincenzo Imperiale. Lettura della Parte V.Studi secenteschi, XXI, 1980, pp.41-107 (in Italian).

18. Lòpez-Bernasocchi A. Una nuova fonte dello Stato rustico di Gian Vincenzo Imperiale: l'Ovidio volgarizzato dell'Anguillara. Studi e Problemi di Critica testuale, 22, 1981, pp. 15-44 (in Italian). 
19. Magnani L. Giovanni Benedetto Castiglione il Grechetto: un vedere 'filosofico'. Libertinismo erudito e pensiero anticonformista. Genova nell'Europa del Seicento, Atti del Convegno di Studi (Genova 5-7 maggio 2011). Roma, Vecchierelli Editore Publ., 2014, pp. 215-234 (in Italian).

20. Magnani L. Laltra superficie del mito: decorazione e tematiche mitologiche tra XVII e XVIII secolo a Genova. Le Metamorfosi del Mito. Milano, Electa Publ., 2003, pp. 29-39 (in Italian).

21. Malfatto L. L'inventario della biblioteca di Anton Giulio Brignole Sale. La Berio, 28 (1988), no. 1, pp. 5-34 (in Italian).

22. Marini Q. Anton Giulio Brignole Sale. La letteratura ligure. La Repubblica aristocratica (1528-1797), vol. 1. Genova, Costa \& Nolan Publ., 1992, pp. 351-389 (in Italian).

23. Martinoni R. Gio. Vincenzo Imperiale. Politico, letterato e collezionista genovese del Seicento. Padova, Antenore Publ., 1983. 324 p. (in Italian).

24. Mattiauda E. Venere e Marte sorpresi da Vulcano. Le Metamorfosi del Mito. Milano, Electa Publ., 2003, p. 95 (in Italian).

25. Montanari G. Lettori di libri, collezionisti di quadri. Lo spazio culturale a Genova tra XVI e XVII secolo attraverso l'analisi delle raccolte librarie. Collezionismo e spazi del collezionismo. Temi e sperimentazioni, a cura di L. Magnani. Roma, Gangemi Publ., 2013, pp.41-52 (in Italian).

26. Montanari G. Libri Dipinti Statue. Rapporti e relazioni tra le raccolte librarie, il collezionismo e la produzione artistica a Genova tra XVI e XVII secolo. Genova, Genoa University Press Publ., 2015. 304 p. (in Italian).

27. Montanari G. Libri e pennelli: dalle 'Vite' di Plutarco agli affreschi di Cambiaso nella Villa Grimaldi-Sauli al Bisagno a Genova. Commentari d'Arte, 61/62, XXII (2016), pp. 42-56 (in Italian).

28. Morando S. La letteratura in Liguria tra Cinque e Seicento. Storia della cultura ligure, vol. 4. Genova, Società Ligure di Storia Patria Publ., 2005, pp. 36-51 (in Italian).

29. Morando S.; Vazzoler F. Orazio De Ferrari scrutinized by Luca Assarino. Orlando A. The Fable of Leto by Orazio De Ferrari. The Return of a Masterpiece. Genova, Sagep Publ., 2016, pp. 41-48.

30. Morandotti A. Gli esordi naturalistici di Giovanni Battista Carlone. Nuovi Studi, 6/7, 2001-2002 (2003), pp. 161-167 (in Italian).

31. Orlando A. The Fable of Leto by Orazio De Ferrari. The Return of a Masterpiece. Genova, Sagep Publ., 2016. $96 \mathrm{p}$.

32. Pesenti F. R. La pittura in Liguria -- Artisti del Primo Seicento. Genova, Sagep Publ., 1986. 400 p. (in Italian).

33. Piantoni L. Per "Lo Stato Rustico" di Giovan Vincenzo Imperiale. Note stilistiche a un poema anti-narrativo. Lettere italiane, 2014, 2, pp. 247-276 (in Italian).

34. Pieri M. L'intelligenza della Galeria. Paragone, 19 (1978), pp. 30 (in Italian).

35. Russo E.; Pignatti F. (eds.). Imperiale (Imperiali), Gian Vincenzo. Dizionario Biografico degli Italiani, Roma, 62, 2004, pp. 297-302 (in Italian).

36. Simonetti F. Le Storie di Ercole di Gregorio De Ferrari dal Palazzo Cattaneo Adorno in Strada Nuova. I Miti. Le fatiche di Ercole. Genova, Tormena Publ., 1998, pp.11-24 (in Italian).

37. Sopranzi G. Le tre redazioni dello Stato rustico di Giovanni Vincenzo Imperiale. R. Reichlin; G. Sopranzi. Pastori barocchi fra Marino e Imperiali. Friburgo, Edizioni Universitarie Publ., 1988, pp. 75-140 (in Italian).

38. Stagno L. La "parentela" di poesia e pittura e due "schizzetti" di Arione e Leda nelle lettere di Gabriello Chiabrera a Bernardo Castello. Lettere italiane, a. LX, no. 1, 2008, pp. 116-126 (in Italian).

39. Stagno L. Mercurio uccide Argo. Le Metamorfosi del Mito. Milano, Electa Publ., 2003, p. 85 (in Italian).

40. Stagno L. Pan e Siringa. Le Metamorfosi del Mito. Milano, Electa Publ., 2003, pp. 59-60 (in Italian).

41. Stagno L. Perseo e Andromeda. Le Metamorfosi del Mito. Milano, Electa Publ., 2003, p. 121 (in Italian).

42. Tasso T. Gerusalemme Liberata, con gli Argomenti del sig. Gio. Vincenzo Imperiale. Genova, per il Pavoni Publ., 1604. 572 p. (in Italian).

43. Vazzoler F. “...Anche dagli scogli nascon pennelli...”: Luca Assarino e i pittori genovesi del Seicento. Le dediche degli Argomenti dei Giuochi di Fortuna, 1655. Studi di storia delle arti, no. 7, Genova, 1991-1994, pp. 35-62 (in Italian).

44. Vazzoler F. L'occhio e il pennello. I letterati genovesi davanti al Sarzana. Domenico Fiasella, a cura di P. Donati, Genova, Sagep Publ. 1990, pp.31-46 (in Italian).

Title. Between Poetry and Painting: Giovanni Andrea dell'Anguillara's Metamorfosi as a Model for Genoese Baroque Poets and Painters.

Author. Giacomo Montanari - research fellow. University of Genova, Via Balbi 4, 16126, Genova (Ge), Italy.gcm.montanari@gmail.com 
Abstract. In a large part of recent studies on baroque iconography, the development of mythological representations and the use of classical sources during the $17^{\text {th }}$ century has been considered. When referring to the sources used by baroque painters, it is quite common to speak generically about "Ovid", and in not many cases we found precise links to one of the edited texts of the Metamorfosi, which were largely used by painters instead of the original Latin version. In the same way, the new "baroque language" used by poets is founded too on the basis of classical poems, revisited by great literates of the $16^{\text {th }}$ century: especially Tasso, Ariosto, and Anguillara. The more logical way of reading the roots of the baroque culture through objects, such as books and works of art, is to understand completely the cultural landscape in which both poets and painters lived and the sources they considered to be "classical" or "antico": a perspective that is radically different from ours.

The aim of this paper is to demonstrate how in Genoa, one of the greatest cities in which the new baroque culture rose, during the $17^{\text {th }}$ century, the book by Anguillara was used both as a model by literates for their baroque rethorical composition and by painters as a more comprehensible and "modern" source of the "antico" for their works of art. The importance of Anguillara's book is well demonstrated by its finding in the most important Genoese libraries of the $16^{\text {th }}$ and $17^{\text {th }}$ century, which have been checked in some recent publications. The great literary works by Luca Assarino and Anton Giulio Brignole Sale, and the painted myths by Orazio De Ferrari, Domenico Fiasella and Gregorio De Ferrari become, from this point of view, important examples of the communitas studiorum that was present in Genoa's Republic all along the $17^{\text {th }}$ century and that made the Ligurian city an important and today still less studied center of the European cultural update.

Keywords: Anguillara; Genoa; Baroque art; Metamorfosis; Ovid; Antique; Baroque literature; Gregorio De Ferrari; Carlone; painting.

Название статьи. Между поэзией и живописью: «Метаморфозы» Джованни Андреа Ангиллара как образец для генуэзских поэтов и художников эпохи барокко.

Сведения об авторе. Монтанари, Джакомо - исследователь. Университет Генуи, Виа Бальби 4, 16126, Генуя, Италия. gcm.montanari@gmail.com

Аннотация. Широко известно значение «Метаморфоз» Овидия в XVI и XVII столетиях как источника вдохновения, особенно для художников. Предметом внимания ученых стало и распространение новых интерпретаций Овидия, таких как «Метаморфозы» Ангиллара, публикация которых была начата в Венеции в 1561 г. Кода речь заходит об источниках, к которым обращались художники, даже в современных исследованиях, посвященных иконографии барокко, развитию мифологических репрезентаций и роли классических источников в XVII столетии, обычно говорят в целом об «Овидии» и лишь иногда встречаются указания на тот или иной конкретный изданный вариант текста «Метаморфоз» а ведь именно эти тексты, а не латинский оригинал, в действительности использовали художники. Точно так же новый «барочный язык» поэзии был основан на классической традиции в той трактовке, которую ей дали великие поэты XVI в. - Тарквато Тассо, Ариосто и Ангиллара. В соответствии с этим, более правильным представляется тот способ интерпретации барочных произведений искусства, когда учитывается культурная среда, в которой жили поэты и художники, и источники, которые они считали «классическими» и «античными», - подход, который решительно отличается от традиционного.

Цель статьи - выявить, как в Генуе, одном из величайших городов, в которых формировалась новая барочная культура, с начала и до конца XVII столетия, книга Ангиллара использовалась писателями для создания барочных риторических композиций и художниками в качестве более понятного и "современного» источника «античного». Важность книги Ангиллара подтверждается фактом ее наличия в наиболее значительных генуэзских библиотеках XVI и XVII вв., что демонстрируют новейшие исследования. Сочинения Луки Ассарино и Антона Джулио Бриньоле Сале и живописные мифы Орацио де Феррари, Доменико Фиазелла и Грегорио де Феррари стали, с этой точки зрения, примечательными примерами communitas studiorum в Генуэзской республике XVII в. Благодаря этому, лигурийский город стал важным, хотя и до сих пор мало изученным центром обновления европейской культуры.

Ключевые слова: Ангиллара; Генуя; искусство барокко; Метаморфозы; Овидий; античность; барочная литература; Грегорио де Феррари; Карлоне; живопись. 


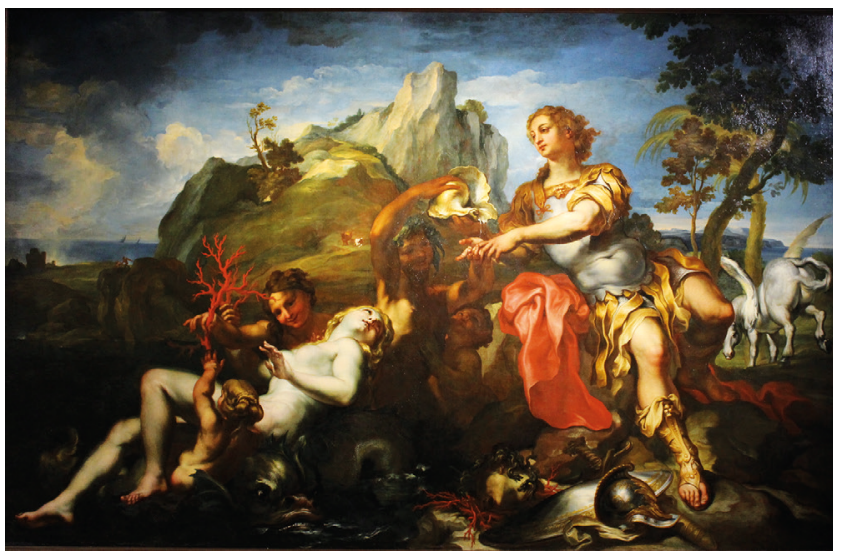

Ill. 21. Lorenzo De Ferrari. Birth of the Coral or Perseus and Andromeda. c. 1700. Galleria Nazionale di Palazzo Spinola, Genoa

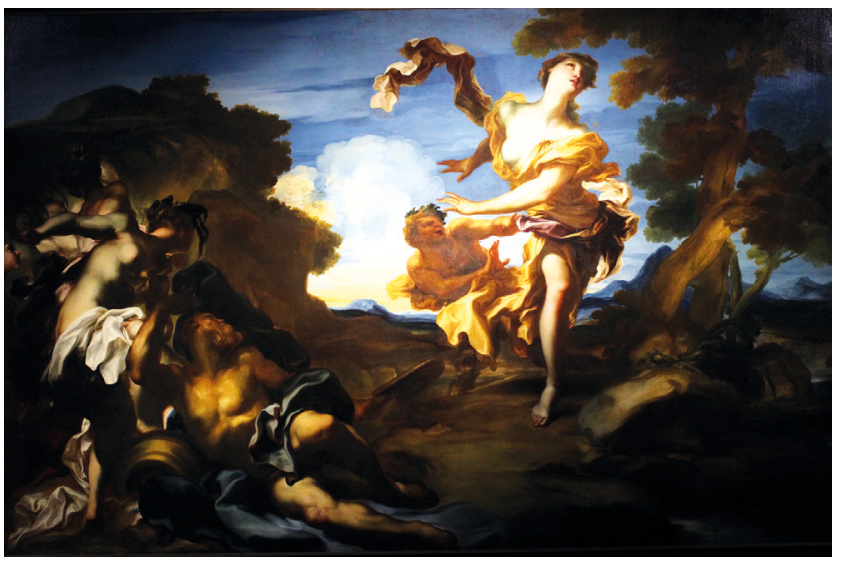

Ill. 22. Gregorio De Ferrari. Pan and Syrinx. c. 1700. Galleria Nazionale di Palazzo Spinola, Genoa

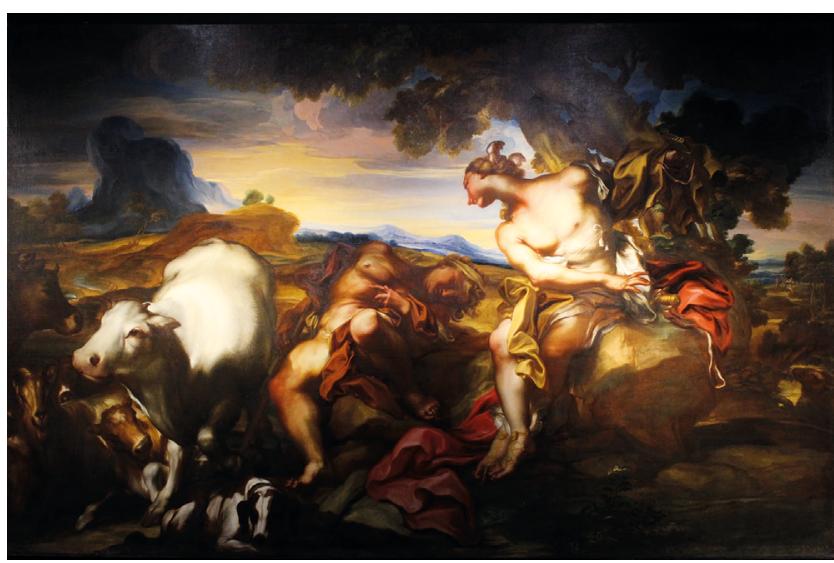

Ill. 23. Gregorio De Ferrari, Lorenzo De Ferrari. Mercury killing Argus. c. 1700. Galleria Nazionale di Palazzo Spinola, Genoa 